\title{
An attempt to indicate numerically for "the anxiety and wariness" of food poisoning
}

\author{
食中毒の「不安と警戒心」に対する数値化の試み
}

\author{
Yoshihiko HIRAI \\ Exergy Studies Associates, Inc. 1330-220 Koshigoe, Kamakura, Kanagawa 248-0033, Japan \\ TEL: 0467-32-1108 FAX: 0467-32-1085
}

( Received 31, January 2003 Accepted 20, February 2003 )

\begin{abstract}
It is known that "knowledge /affection /consciousness" called 3 functions are in the brain of the person. Two functions of "the affection /consciousness" are perceived among these in this research. Thereupon, what kind of signal appears in the electroencephalogram (EEG) is checked empirically, when the testee smelled the stench of the food that set the corruption.

The result of the EEG is reproduced to the line signals of 3 dimension from the chronological order signal of 1 dimension by using the method of Ruell and Takenns. Thereupon, the line signals of 3 dimension is done in the phase space of 3 dimension the copy picture. As for the attractors of 3 dimension the cross section is requested by the method of Poincare'e. Also, the return map is painted from this cross section. It expresses the complexity of the return map with the fractal dimension last, and make this the material and the attempt of numerical value-ization of "the anxiety and wariness" of food poisoning is proposed.
\end{abstract}

Keywords : the affection/consciousness, method of Ruell and Takenns, Poincare'e section, return map, fractal dimension, numerical value-ization

\section{INTRODUCTION}

人工知能の研究が進むにつれて、脳の機能をコンピュ 一タで置き換えようとすると、その大きさは地球よりも 大きくなり、1 万年もかからないと答えが出てこないこ とがわかった。このことから、人間の知的な活動は、膨 大な計算をしているのではなくて、例えば、「注意」と呼 ばれるような、関係のない情報は全部捨てて、今ここだ け見ていればよいと言う所に焦点を合わせている「情動 システム」のようなものが機能していると予想されてい る。 1

脳には，知・情・意と呼ばれる三機能のあることが知 られている。従来、多くの脳科学者は「心」に関わる情 · 意の機能は哲学や心理学の領域に任されるべきであると の考えから、専ら第一の機能である知に関心を寄せてき た。しかし、最近の脳科学では、上記の例のように、知 の機能を理解する上で、また応用の面で、情・意の機能 の重要性が認められ、その機能に関心が向けられるよう になった。 2
本研究は、上述のような研究背景の下に、情・意の機 能のうち極く限られた分野を取り上げて、初歩的な実験 を行った。実験では、被験者が腐敗しかけた食物の悪臭 を嗅いだ際に、脳波(EEG)にどのような信号が現れるか を調べた。

情・意の機能は、いずれも「心の動き」に関わるので、 「心の動き」のうち、どこからが「情」で、どこからが「意」 と言うように線を引くことが難しい。そこで、便宜的に、 被験者が「悪臭への不快感と不安感」を感じたとき、こ れは「情」の働きによるものと仮定し、被験者が「食中 毒に対する危険の意識（警戒心）」をもったとき、これは 「意」の働きによるものと仮定した。

本稿では、実験で得られた脳波をカオス解析し、その 解析で得られた図形のフラクタル次元を求めている。そ の結果、フラクタル次元の数值を用いることによって、 元来、漠然とした「不安と警戒心」と言う抽象的な概念 に対して数值化の一つの試みを提案している。 


\section{EXPERIMENTAL}

実験対象として、広範な「情・意」の機能のうち特に 臭覚に関わる事例を選んだのは、次の理由によった。一 つは、猫が物を食べる前に必ずその臭いを嗅ぐ行動は原 始的な摂慨行動と言われている。人の場合も類似した行 動をとることがある。臭脳は、脳野の進化の過程で最も 原始的な発生とされ、この行動は生命の安全を守る本能 に由来すると言われている。3 そこで、実験対象をで きるだけ単純なものとするために、鮮度の落ちた食物に 感ずる本能的な不安と、食中毒に対する危険の意識（警 戒心）を選んだ。二つは、呼吸器機能障害者に認定され ている親族の介護をしている者にとり、身近で関心のあ る問題であったからである。

測定条件は、簡単な二つの場合が設定された。EEGの 測定は連続して行われ、最初、被験者が初めて腐敗しか けた食物の悪臭を嗅いだ直後から 10 秒間の波形を第一 のデータとして採択し、次に、30 分後に、何回も悪臭を 嗅いだ後の 10 秒間の波形を第二のデータとして採択し た。

このとき、第一のデータには「悪臭への不快感と不安 感」の信号が含まれ、第二のデータには「食中毒に対す る危険の意識 (警戒心)」の信号が含まれると仮定した。 以後は記述の簡便のために、前者の信号は「不安」と略 記し、後者の信号は「警戒」と略記した。

脳波測定の電極位置は、10 120 法に準拠し、 $\mathrm{F}_{\mathrm{P} 1}$ と $\mathrm{F}_{\mathrm{P} 2} 、 \mathrm{~F}_{1}$ と $\mathrm{F}_{2}$ (添え字の数字は奇数が左脳、偶数が右 脳を表している）の部位に設置された。また、当該部位 の電位は双極誘導法によって検出された。

検出された微弱信号の増幅は、本研究室製のオペアン プ (EMG-HIRAI 1000,EMG-HIRAI 1001) によった。この 装置は、前置増幅器と主増幅器からなり、両者の間は光 ファイバーで結合されている。電気信号が光信号に変換 されて電気的に遮断された回路が用いられている理由は、 記録装置の電源を経由して雷によるサージ電圧が被験者 に及ばないためである。

脳の 2 次的な反忘を知るため、左手の中指に光学的な 検出装置が装着され、脳波測定と同時刻に、並行して指 尖脈波が測定された。脈波の検出装置及び信号増幅装置 は、日本光電工業（株）社の PHOTOELECTRIC PLETHYSMOGRAPH (MPP-3U) が用いられた。

測定データの処理は、一旦、横河電機株式会社製のア ナライジングレコーダ（AR1100A）に記録して、内蔵の ドライバによってF Dに保存し、次に、これをパソコン に入力して、ヒューリンクス社の FlexProVer.6 を用いて 解析を行う方法を採用した。

\section{RESULTS AND DISCUSSION}

\section{III-A. Fundamental data}

本研究での基礎データは、脳波と脈波を同時刻に測定 し、A／D変換して、アナライジングレコーダに記録し たデータを指す。代表例を Fig. 1 に掲げた。

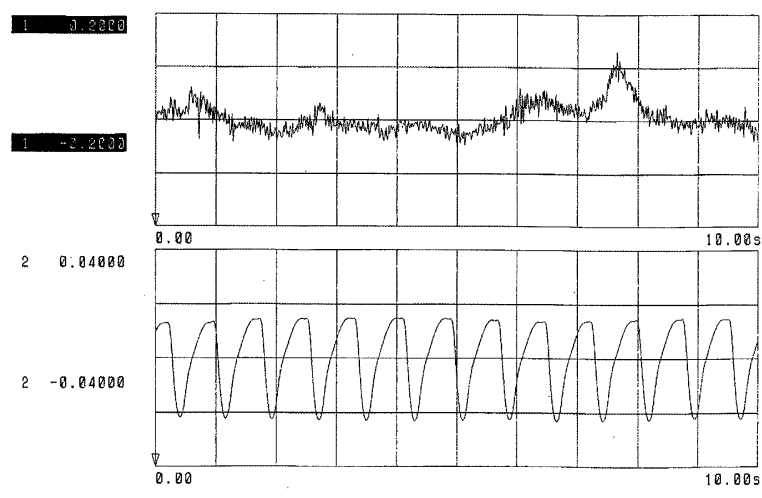

Fig.1. The electroencephalogram (the top) and pulse wave (under) of the Wary condition.

測定条件は、サンプリング速度：100Hz、記録時間： $10 \mathrm{sec} 、$ データ個数：1000 個である。

同時刻にアナライジングレコーダの 2 チャンネルに記 録された基礎データは、FlexProVer.6によって脳波と脈波 の別に解析された。

先ず、脳波 (electroencephalogram:EEG) について、平 常時の解析波形を Fig.2 に、不安時の解析波形を Fig. 3 に、 警戒時の解析波形を Fig.4 に掲げた。

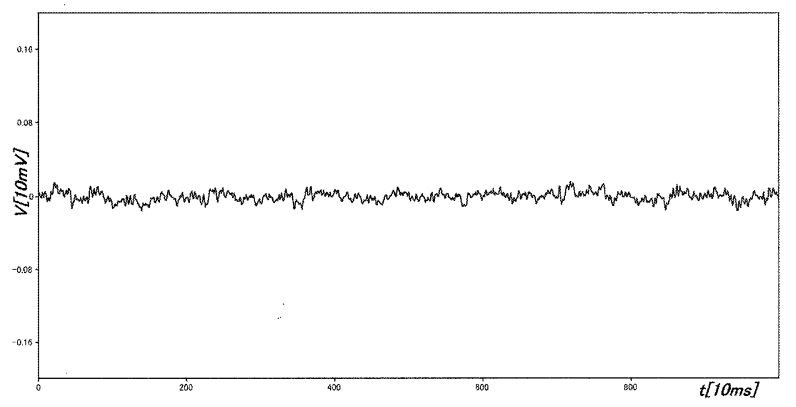

Fig.2. The EEG of the Usual condition.

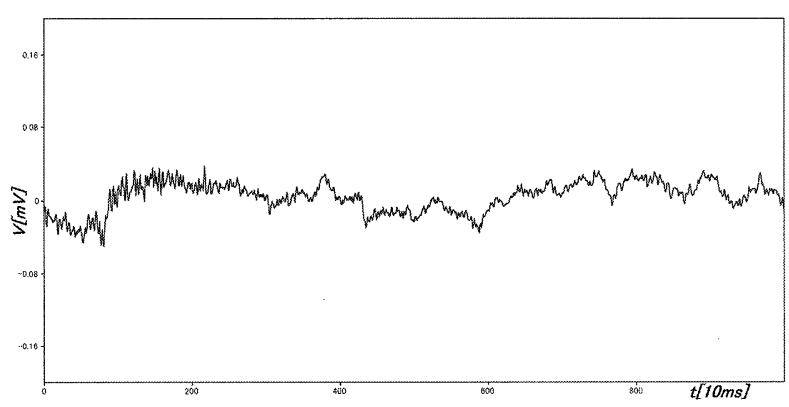

Fig.3. The EEG of the Anxious condition. 


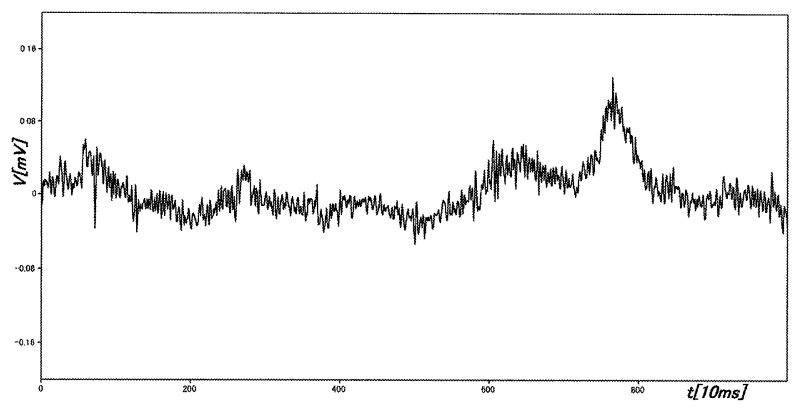

Fig.4. The EEG of the Wary condition.

上掲の三図は、共通して縦軸が電位、横軸が時間を表 している。Figure 2 の脳波は、振幅が約 $20 \mathrm{mV}$ で、一様 な波形が観測される。Figure 3 の脳波は、基本振幅が約 $20 \mathrm{mV}$ と変わらないが、短い基本周期の波が長周期の 波に重畳している。Figure 4 の脳波は、基本振幅は約 $40 \mathrm{mV} \sim 60 \mathrm{mV}$ で、Fig.2 やFig.3 の振幅の数倍であり、Fig.3 と同様に異なる周期の重畳波形になっている。

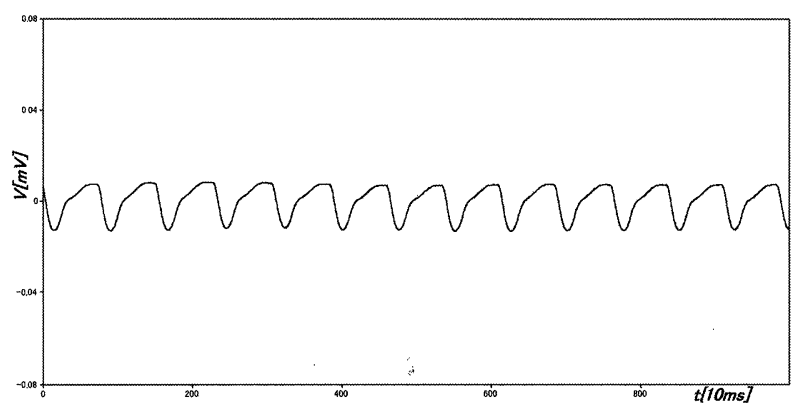

Fig.5. The PG of the Usual condition.

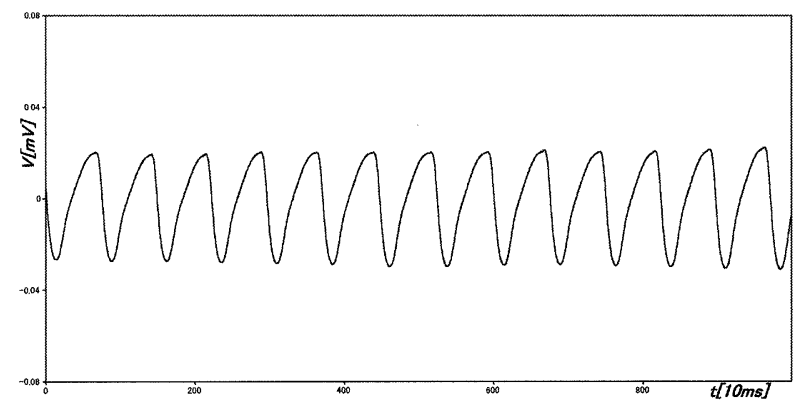

Fig.6. The PG of the Anxious condition.

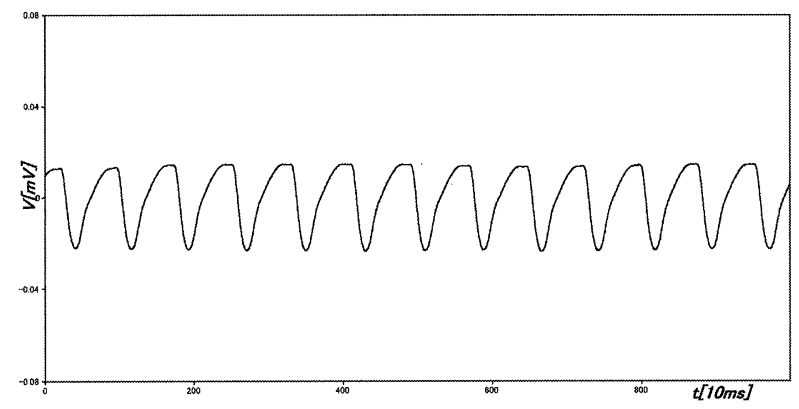

Fig.7. The PG of the Wary condition.
次に、脈波(plethysmograph:PG)について、平常時を Fig.5 に、不安時を Fig.6に、警戒時を Fig.7 に掲げた。

上掲の三図は、共通して縦軸が電位、横軸が時間を表 している。Figure 5 の脈波は、振幅が約 $10 \mathrm{mV}$ で,脈拍が $78 \mathrm{bpm}$ である。Figure 6 の脈波は、振幅が約 $20 \mathrm{mV}$ と平 常時の約 2 倍に達しているが、脈拍が $78 \mathrm{bpm}$ と変わらな い。振幅の大きさでみる限り、不安による生体の反応は、 脳波よりも脈波に現れている。これは、心の動きが生体 の各器官に比較的迅速に反映されるためとみられ、とり わけ心臟は、感情表現の 2 次的な器官として関心がもた れる。Figure 7 の脈波は、振幅が約 $15 \mathrm{mV}$ で、平常時と 不安時の中間の值を示し、脈拍が $78 \mathrm{bpm}$ と変わらない。 振幅が不安時の值よりも低くなってきたのは、意識の働 きの段階では不安が沈静の方向に向かっていると推定さ れる。

\section{III-B. Results of Fourier analysis}

情・意に関する脳波の信号として、「注意力」に関わる P 300 脳波と呼ばれる信号の存在が知られている。4 即ち、被験者の耳元でカチっと言う鋭い音をたてると、 その直後に被験者の脳波には、減衰振動波形を時間的に 逆に再現したような、一連の波形が現れる。これは、鋭 い音刺激に対する脳の反応と考えられ、被験者にある種 の「注意力」が働いたものと解釈されている。Figure 8 は、文献 4 から引用した。

P 300 脳波と呼ばれる由来は、「注意力」によって発 生したと思われるこの脳波が、通常、刺激から $300 \mathrm{msec}$ 後に現れるためで、PはPositive（正）を表している。同 図の記法で、Nは Negative（負）を表している。また、 2 と 3 は 100 の桁を省略したものである。同図から推 定されるように、必ずしも刺激後、正確に $300 \mathrm{msec}$ に出 現するものではなく、300 msec 前後に出現するものと考 えるのが妥当であろう。また、同図で、実線は通常脳波、 破線は予告した場合、点線は予告なしの場合である。 $\mathrm{P}$ 3 の電位は約 $14 \mu \mathrm{V}$ と読み取れる。

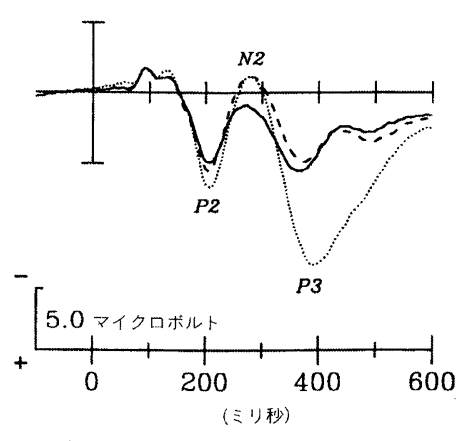

Fig.8. P300-EEG yielded by the "Attention" 4 
本研究では、このP 300 脳波に着目し、測定した 3 種類の脳波について、その周波数成分を知るために、波 形の高速フーリエ変換（FFT）を行った。Figure 9 に平常 脳波の解析結果を、Fig.10 に不安脳波の解析結果を、

Fig.11 に警戒脳波の解析結果を掲げた。

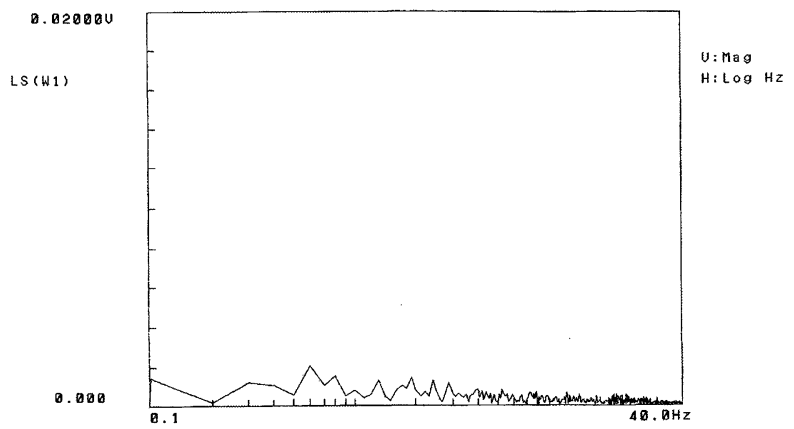

Fig.9. FFT of the Usual EEG.

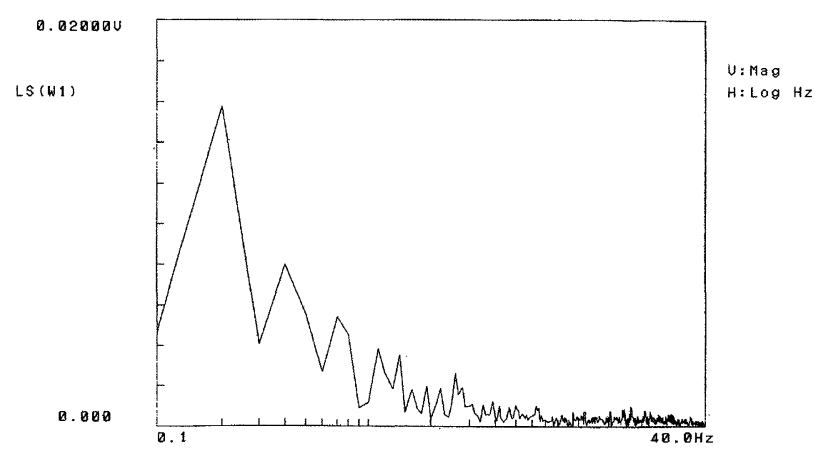

Fig.10. FFT of the Anxious EEG.

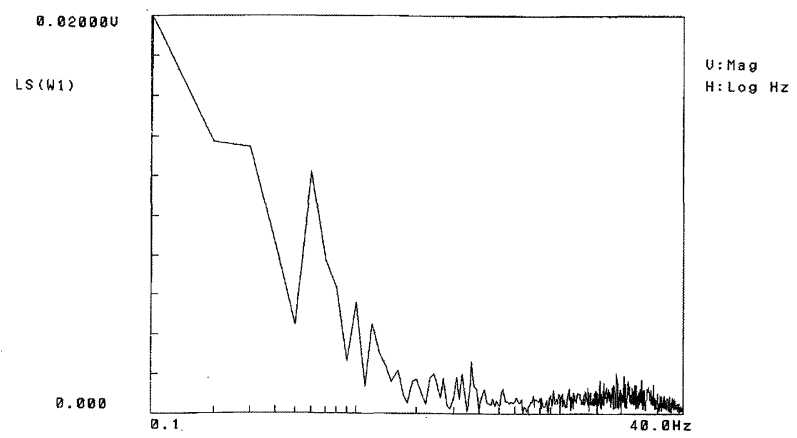

Fig.11. FFT of the Wary EEG.

$300 \mathrm{msec}$ の逆数は約 $3.3 \mathrm{~Hz}$ である。上掲の 3 図を調べ ると、Fig.9では、3Hz帯に顕著なピークが見当たらない。 それに対し、Fig.10 と Fig.11では、3Hz 帯に顕著なピー クが見られる。P 300 脳波は聴覚に対する音刺激の場 合であり、本実験の場合は臭覚に対する臭い刺激である ので、 $3 \mathrm{~Hz}$ 帯のピークの存在を以て、直ちに「注意力」 に関わる P 300 脳波の存在を断定できないが、P 30
0脳波かどうかの判定は別として、平常状態の脳波にな い信号が、不安状態脳波と、警戒状態の脳波に存在する 事実は否定できない。

次に、脈波に対しても同様の解析を試みたので、Fig.12 に平常脈波の FFT を、Fig.13に不安脈波の FFTを、Fig.14 に警戒脈波の FFT を掲げた。

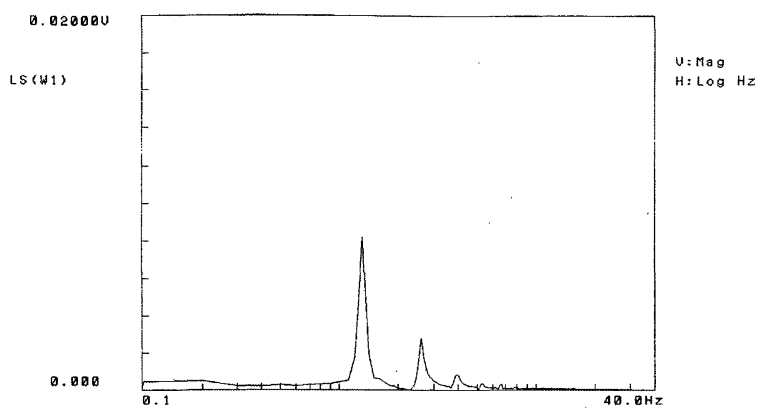

Fig.12. FFT of the Usual PG.

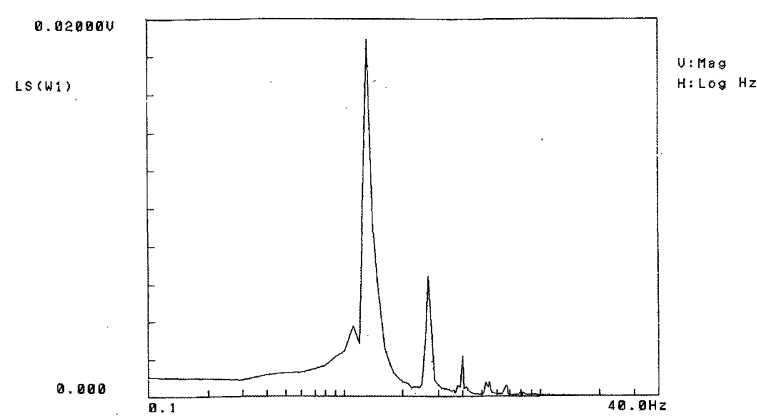

Fig.13. FFT of the Anxious PG.

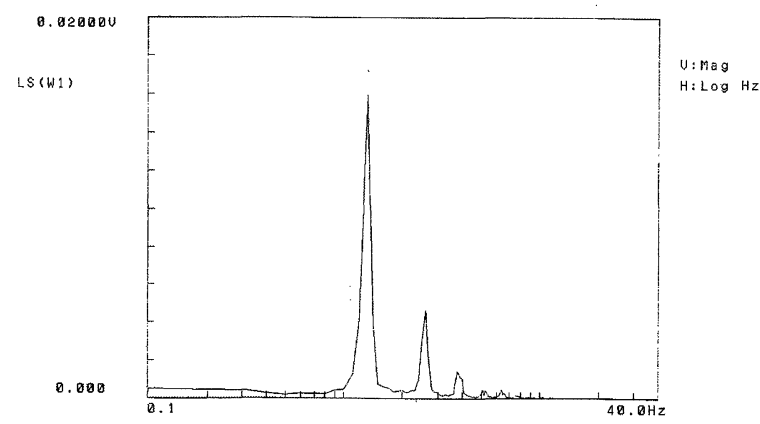

Fig.14. FFT of the Wary PG.

上掲の 3 図とも共通して、 $1.3 \mathrm{~Hz}$ に顕著なピークが見 られるが、これは、明らかに $78 \mathrm{bpm}$ のピークである。そ の他、 $2.6 \mathrm{~Hz}$ と $3.3 \mathrm{~Hz}$ に見られる小さなピークは、主波 の整数倍の高調波に相当している。

上掲の 3 図は、それぞれ振幅は異なっているが、原波 形の波の強さを反映しているもので、波の周波数成分に は顕著な違いが見られない。よって、脈波のフーリエ解 析からは、情・意に関する信号が脈波のなかに含まれて 
いるかどうかと言う情報は得られなかった。よって、今 回の解析では、脈波は参考にとどめた。

\section{III-C. Results of chaos analysis}

基礎データをカオス解析するために、リュエルとター ケンスの方法を用いて、1 1 次元の時系列信号を 3 次元の 列信号に合成した。そこで、3 次元の列信号を 3 次元の 位相空間に写像した。

平常脳波のアトラクタをFig.15に、不安脳波のアトラ クタをFig.16に、警戒脳波のアトラクタを Fig.17 に、そ れぞれ掲げた。

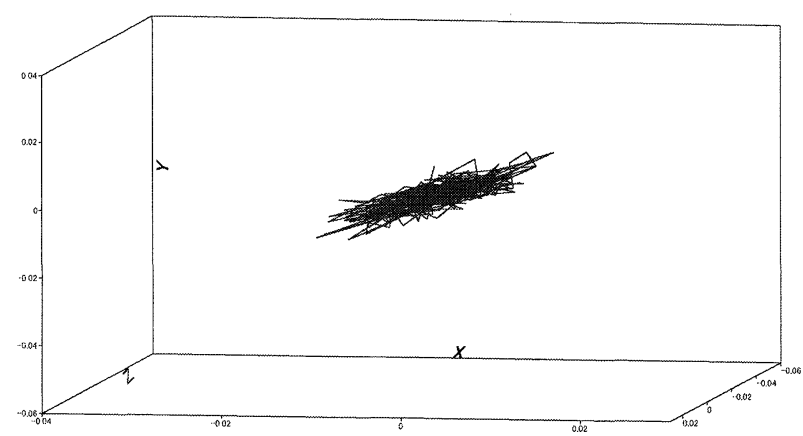

Fig.15. Attractor of the Usual EEG.

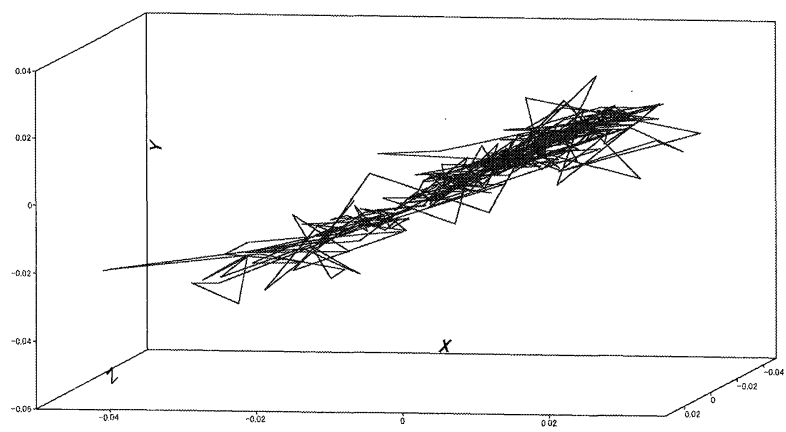

Fig.16. Attractor of the Anxious EEG.

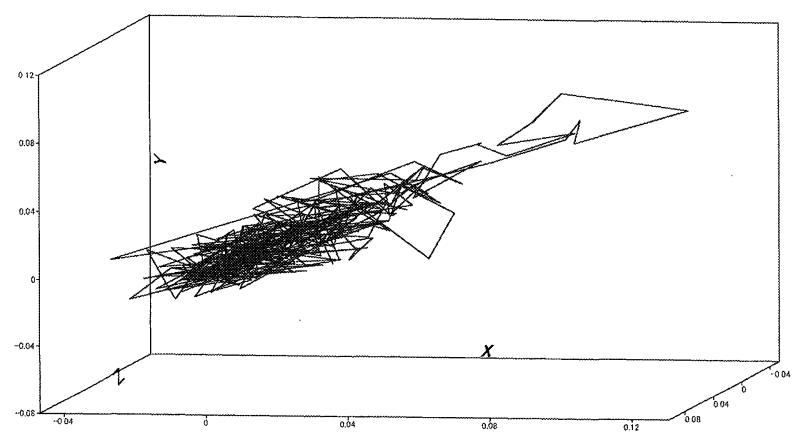

Fig.17. Attractor of the Wary EEG.
上掲の 3 図の座標は、比較の便のために同目盛である。 Figure 15 は小さくまとまり、Fig.16 は大きく広がり、 Fig.17 は大きいが一部まとまっている。また、形状を主 観的に見ると、Fig.15 は沈静を表すような丸みがあり、 Fig.16 は不安を表すかのように複雑な突起があり、Fig.17 は意識過程の収束を表すかのように不安時の複雑な突起 と平常時の丸みの雨者を備えている。然し、これらは、 アトラクタの外観による観察者の主観であり、より客観 的な解析が必要である。

今、3 階非線型常微分方程式のアトラクタの構造を解 析するために、適当な 2 次元曲面 $\Sigma$ でアトラクタを切断 すると、この $\Sigma$ から $\Sigma$ の 2 次元写像 $\mathrm{P}$ 考察することが 可能である。これは、 3 階非線型常微分方程式は P によ って得られた 2 階の差分方程式に帰結できることを意味 している。 5 このような数学的な根拠から、切断された 2 次元の断面には 3 次元のアトラクタの情報が写されて いると考えることができる。なお、断面の 2 次元写像を 慣例としてポアンカレセクションと呼んでいるので、本 稿でもそれに従った。

Figure 15 の 3 次元断面表示を Fig. 18 に、併せて、Fig.19 に、Fig.15 のポアンカレセクションを掲げた。

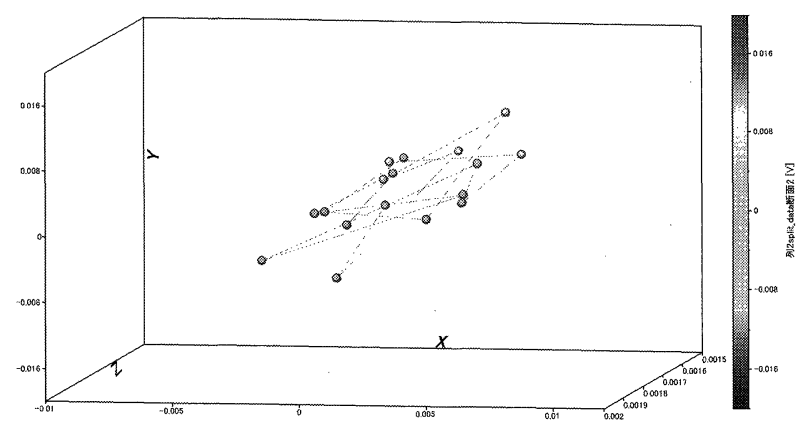

Fig.18. Cross section of the Fig.15.

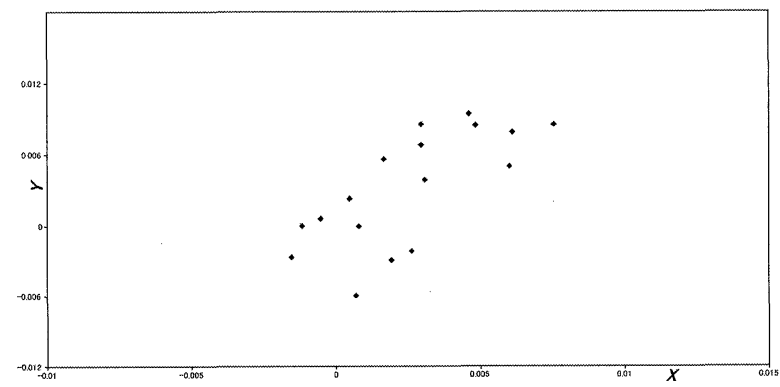

Fig.19. Poincare'e section of the Usual EEG. 
Figure 18 のような 3 次元断面表示は、従来行われてい なかったが、断面の立体的な状態がわかり、本図からア トラクタの構造は比較的平坦であると推定される。

Figure19 のポアンカレセクションは、元の 1000 個のデ ータに対して僅か 10 数個のデータに減少しているが、こ のデータに元の情報が写されていると考えられる。

Figure 20 に Fig. 16 のアトラクタの 3 次元断面表示 を,Fig.21に Fig.16のポアンカレセクションを掲げた。

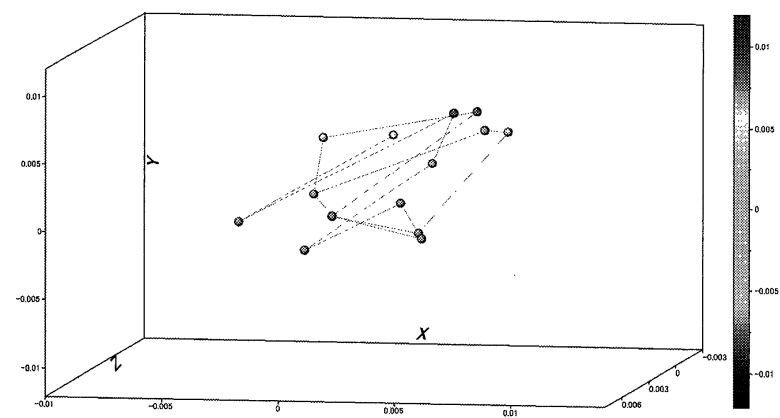

Fig.20. Cross section of the Fig.16.

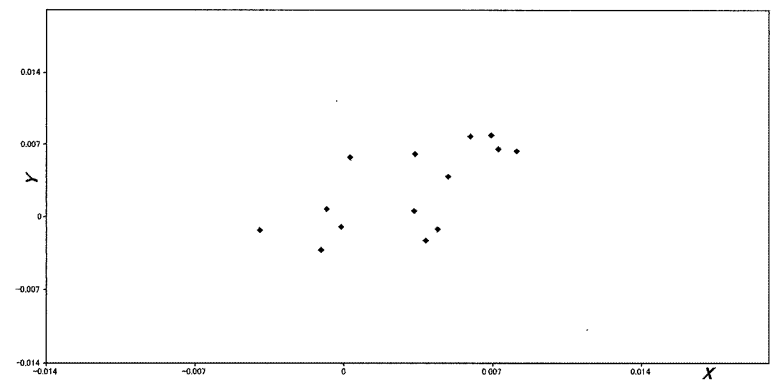

Fig.21. Poincare'e sectionof the Anxious EEG.

Figure 20 は、不安脳波のアトラクタが平常脳波のそれ に比べて広がっているために、断面のデータ分布が粗に なっている。また、Fig.21にみられる不安脳波のポアン カレセクションは、平常脳波のそれに比べて閉曲線の縁 がよりぼやけている。

Figure 22 に Fig. 17 のアトラクタの 3 次元断面表示を、 Fig.23に Fig.17 のポアンカレセクションを掲げた。

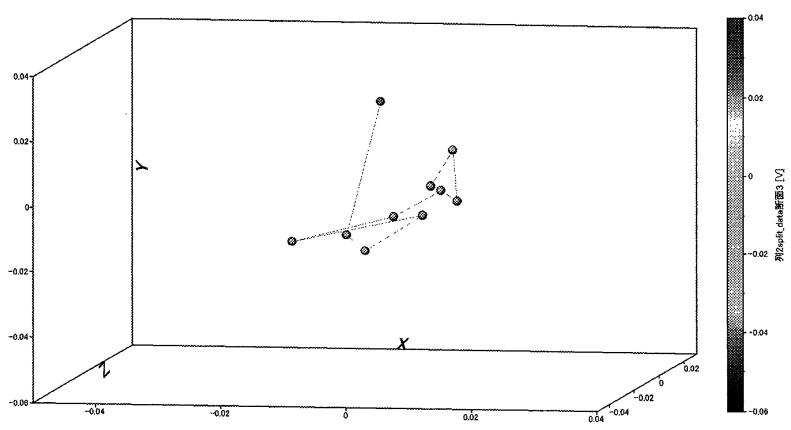

Fig.22. Cross section of the Fig.17.

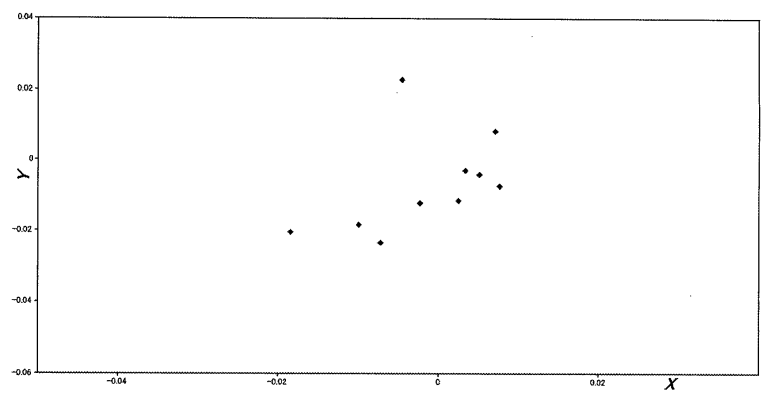

Fig.23. Poincare'e section of the Wary EEG.

Figure 22 は、平常脳波と不安脳波の 3 次元断面表示と 比べて、滑らかさがなくなり、皺（この分野で用いる用 語）ができている。また、Fig.23 は、前 2 者に比べて、 ポアンカレセクションの形状が潰れている。これらは、 警戒脳波のアトラクタの平坦な構造を示す。

なお、脈波についても同様に 3 次元断面表示とポアン カレセクション求めた。然し、前節で述べた通り、フー リエ解析した結果からは、情・意の信号の有無を判定し 難く、かつ、ポアンカレセクションの場合にも、情・意 に関して顕著な信号を見いだすことができなかったので、 本稿では、図面の掲載や解析を省略した。

一般に、カオスとは、有限個の変数ベクトル $\mathrm{x}$ $\left(\mathrm{x}_{1}, \mathrm{x}_{2} \ldots \mathrm{x}_{\mathrm{n}}\right)$ の従う常微分方程式が生み出す非周期運動を 指す。今、変数ベクトル $\mathrm{x}(\mathrm{t})$ の張る $\mathrm{N}$ 次元空間を相 空間と呼ぶと、 $x(t)$ は時間 $t$ の経過と共に、相空間の なかに軌跡を描いていく。このとき、カオスを生み出す 機構は、主に、軌道の不安定性と軌道の閉じこめである。 カオス的になると、軌道は出発点の情報を急速に失いな がら極めて複雑な図形を描く。6

本稿では、切断面に現れる閉曲線が取り囲む領域の或 る一点を原点に固定し、ここから測って、閉曲線を次々 に形成していく軌道の座標 $\left(\mathrm{x}_{\mathrm{n}}, \mathrm{y}_{\mathrm{n}}\right)$ の偏角を、 $\Theta_{\mathrm{n}}=\arctan \left(\mathrm{y}_{\mathrm{n}} / \mathrm{x}_{\mathrm{n}}\right)$ として計算した。このとき、写像 $\mathrm{f}: \Theta_{\mathrm{n}} \rightarrow \Theta_{\mathrm{n}+1}$ が定義されるので、( $\Theta_{\mathrm{n}}, \mathrm{f}\left(\Theta_{\mathrm{n}}\right)$ を描いた ものである。この $\mathrm{f}$ はリターンマップ (return map)と呼 ばれる。

Figure 24 に平常脳波のリターンマップを、Fig.25 に不 安脳波のリターンマップを、Fig.26に警告脳波のリター ンマップを掲げた。

通常、軌道を調べるのに用いられるリターンマップは、 見方を変えると、切断面に現れる閉曲線が取り囲む領域 (ポアンカレセクション) の内部に入ることである。内部 の一点から座標 $\left(\mathrm{x}_{\mathrm{n}}, \mathrm{y}_{\mathrm{n}}\right)$ の偏角を求めることは、あたか もプラネタリュムの中で、投影された天空の星をある断 面に沿って観測しながら 360 度一周して元に戻るイメー 
ジに似ている。そこで、大胆な仮説が許されるならば、 脳波のリターンマップを解析することは、入ることの困 難な人の心の内部に入ることに相当すると思われる。言 い換えると、写像 $\mathrm{f}$ は、複雑な人の心の軌跡を写してい る筈なので、本稿で目的とした情・意の情報もここに存 在していると考えられる。

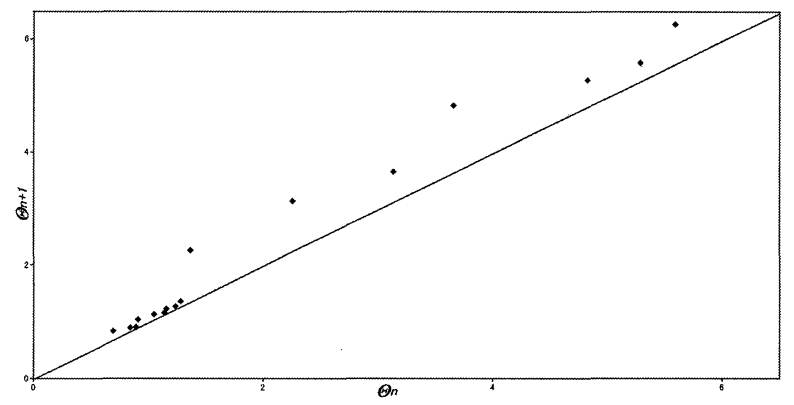

Fig.24. Return map of the Usual EEG.

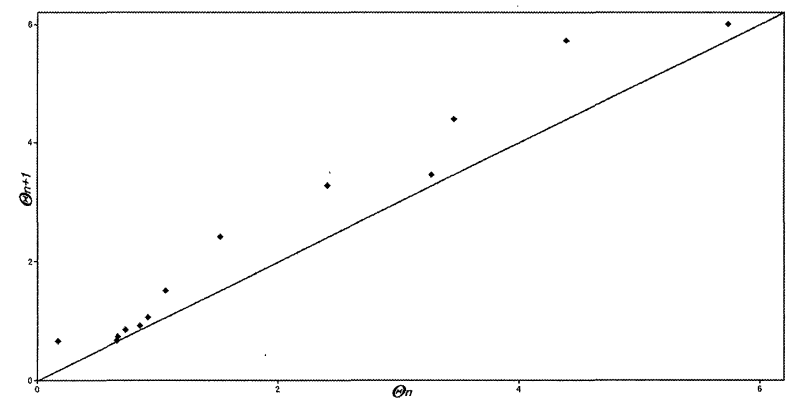

Fig.25. Return map of the Anxious EEG.

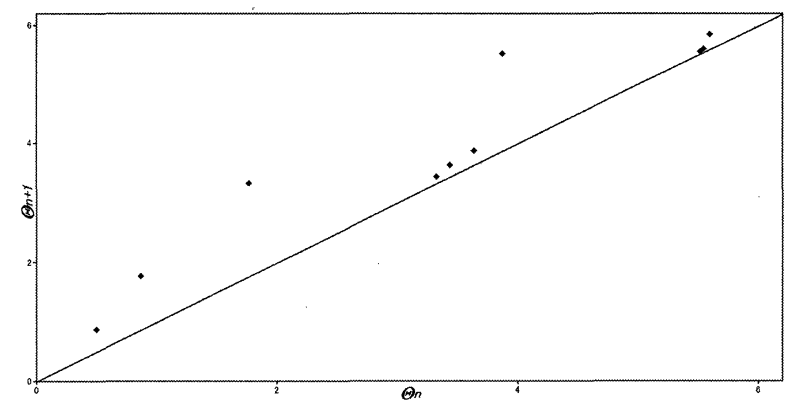

Fig.26. Return map of the Wary EEG.

今、上掲の 3 図を見ると、切断面の点分布は、対角線 に沿って離れては、また近づくと言うパターンが共通し ている。そのパターンは、流体力学系の解析でよく見ら れる「カオスへの遷移状態」に酷似している。すなわち、 非周期的状態を示している。 ${ }^{7} し$ か、点分布の複雑性 に関しては、3者は明らかに相違がみられる。そこで、 以下に、3 者の複雑さを表すフラクタル次元を求めた。

\section{III-D. Fracial dimensions of complexity}

カオスの場合、その軌道は、相空間内でストレンジア トラクタと呼ばれるフラクタル（非整数）な次元をもつ 奇妙な図形に引き込まれ、その中を不安定にさまよい続 ける。このカオスの軌道は、安定性と不安定性が共に内 在する。

一方、ハウスドルフによって定義されたフラクタル次 元を㛜密に求めることはかなり困難である。そこで、本 稿では、一般に用いられている、幾何学的な図形（円や 正方形）で被覆する近似法を採用した。

正方形による細分で測るフラクタル次元は、次のよう である。対象とする図形Xが、ある平面に存在するとす る。その平面を 1 辺が $\mathrm{d}$ の正方形で分割することにより、 図形 Xが正方形 $\mathrm{N}$ （d）個で覆われたとする。このとき のハウスドルフ $\mathrm{k}$ 次元測度は、

$$
M^{k}(X) \approx \lim _{d \rightarrow 0}\left\{N(d) \times(\sqrt{2} d)^{k}\right\}
$$

と考えてよい。ここで、ある定数 $\mathrm{k}$ 。において、いろい ろな 1 辺 $\mathrm{d}$ に対し正方形の個数 $\mathrm{N}$ （d）を測定したとこ ろ、 $N(d) と d^{-\mathrm{k} 0}$ の間に比例関係

$$
N(d) \approx \mu \cdot d^{-k 0}
$$

があるとすれば

$$
\lim _{d \rightarrow 0}\left\{N(d) \times(\sqrt{2} d)^{(k 0)}\right\} \approx \sqrt{2}^{k 0} \cdot \mu
$$

となる。よって、Xのハウスドルフ $\mathrm{k}$ 次元測度 $\mathrm{M}^{\mathrm{k} 0}$ は $\mathrm{k}=\mathrm{k}_{0}$ において

$$
M^{k 0}(X) \approx(\sqrt{2})^{k 0} \mu
$$

という有限確定な值をもつ。そこで、この定数 $\mathrm{k}$ 。を図 形のフラクタル次元と定義する。8

今、 $\mathrm{N}(\mathrm{d})$ と $\mathrm{d}^{-\mathrm{k} 0}$ の式の自然対数をとると、

$$
\ln N(d)=-k_{o} \ln d+\ln \mu
$$

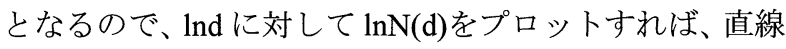
が得られ、その勾配の絶対值 $\mathrm{k}_{0}$ が図形 $\mathrm{X}$ のフラクタル 次元として求められる。

Figure 24 と Fig.24、及び Fig.26に対して、上記の方法 を適用した結果、何れの場合も、比較的よい直線性が得 られた。代表例として、警戒脳波の場合（Fig.26）の解 析例を、Fig.27 から Fig.29まで掲げた。 


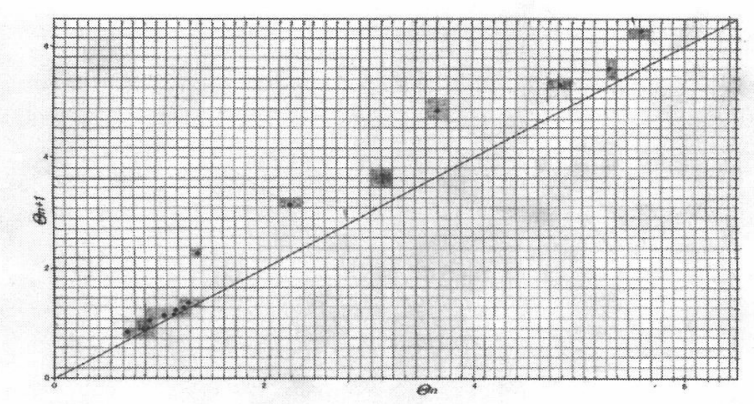

Fig.27. Covering by the Square $(\mathrm{d}=3 \mathrm{~mm})$.

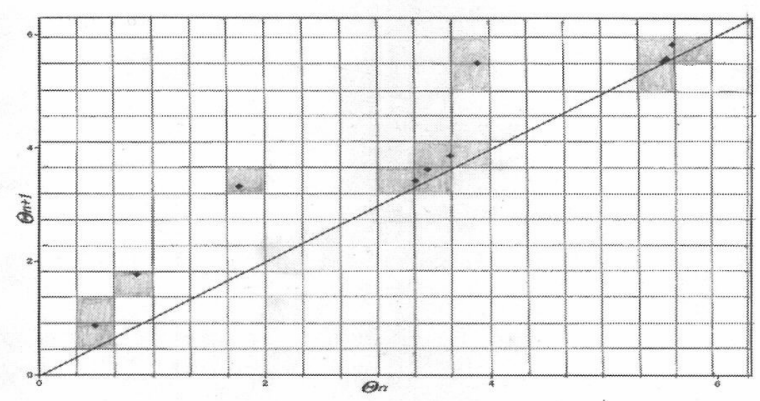

Fig.28. Covering by the Square $(\mathrm{d}=9 \mathrm{~mm})$.

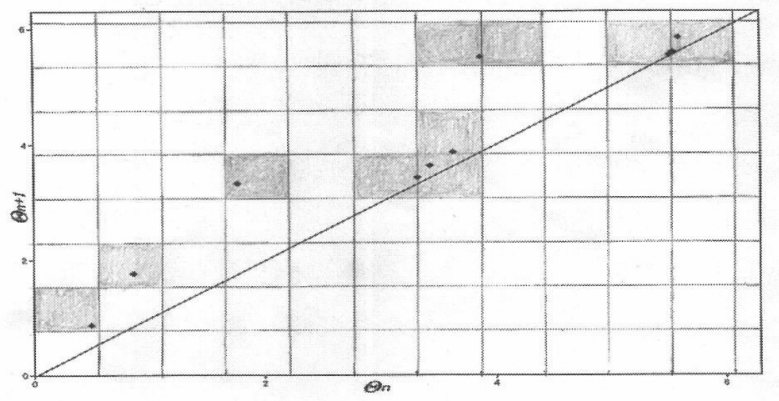

Fig.29. Covering by the Square $(\mathrm{m}=15 \mathrm{~mm})$.

先ず、 1 辺が $\mathrm{d}=3 \mathrm{~mm}$ の正方形で被覆された場合の正 方形の数 $\mathrm{N}(3)$ を求めた。続いて、 $3 \mathrm{~mm}$ づつ増やして、 $\mathrm{d}=15 \mathrm{~mm}$ まで 5 種類の大きさの正方形によって被覆され た場合の $\mathrm{N}(\mathrm{d})$ 老、逐次求めた。上掲の図は、そのうちの 3 例である。すなわち、 $\mathrm{d}=3 \mathrm{~mm}$ の場合の $\mathrm{N}(3)=24 、 \mathrm{~d}=9 \mathrm{~mm}$ の場合の $\mathrm{N}(9)=13 、 \mathrm{~d}=15 \mathrm{~mm}$ の場合の $\mathrm{N}(15)=10$ と読みと れる。図を揭載しなかった $\mathrm{d}=6 \mathrm{~mm}$ と $\mathrm{d}=12 \mathrm{~mm}$ の場合を 含め $\mathrm{d}$ の単位を $\mathrm{cm}$ として、 $\mathrm{d}$ と $\mathrm{N}(\mathrm{d})$ について警戒脳波 の測定結果を Table 1 に掲げた。

Table 1. Results of the Wary EEG.

\begin{tabular}{c|c|c|c|c} 
No. & $\mathrm{d}$ & $\mathrm{N}(\mathrm{d})$ & $\ln \mathrm{d})$ & $\ln \mathrm{N}(\mathrm{d})$ \\
\hline 1 & 0.3 & 24 & -1.204 & 3.178 \\
\hline 2 & 0.6 & 16 & -0.511 & 2.773 \\
\hline 3 & 0.9 & 13 & -0.105 & 2.565 \\
\hline 4 & 1.2 & 11 & 0.182 & 2.398 \\
\hline 5 & 1.5 & 10 & 0.406 & 2.303
\end{tabular}

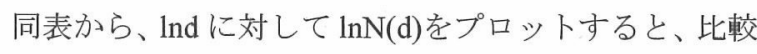
的よい直線性が得られ、その勾配は、 -0.56 と示された。 これから、警戒脑波から得られたリターンマップのフラ クタル次元（以後、警戒脑波のフラクタル次元と略記） は、0.56 と推定された。

平常脳波について、前例と同様の手法で解析した結果 を Table 2 に掲げた。

Table 2. Results of the Usual EEG.

\begin{tabular}{c|c|c|c|c} 
No. & d & N(d) & In d & In N(d) \\
\hline 1 & 0.3 & 28 & -1.204 & 3.332 \\
\hline 2 & 0.6 & 15 & -0.511 & 2.709 \\
\hline 3 & 0.9 & 13 & -0.105 & 2.565 \\
\hline 4 & 1.2 & 12 & 0.182 & 2.485 \\
\hline 5 & 1.5 & 12 & 0.406 & 2.485
\end{tabular}

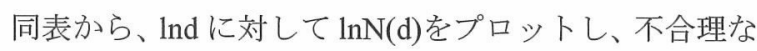
No.5 のデータを除いて、その勾配を求めると、 -0.70 と 示された。これから、平常脳波から得られたリターンマ ップのフラクタル次元（以後、平常脳波のフラクタル次 元と略記）は、0.70 と推定された。

不安脳波について解析した結果を Table 3 に掲げた。

Table 3. Results of the Anxious EEG.

\begin{tabular}{c|c|c|c|c} 
No. & $\mathrm{d}$ & $\mathrm{N}(\mathrm{d})$ & $\ln \mathrm{d}$ & $\ln \mathrm{N}(\mathrm{d})$ \\
\hline $\mathbf{1}$ & 0.3 & 26 & -1.204 & 3.258 \\
\hline 2 & 0.6 & 19 & -0.511 & 2.89 \\
\hline 3 & 0.9 & 13 & -0.105 & 2.565 \\
\hline 4 & 1.2 & 14 & 0.182 & 2.639 \\
\hline 5 & 1.5 & 9 & 0.406 & 2.197
\end{tabular}

同表から、 Ind に対して $\ln N(\mathrm{~d})$ をプロットし、平均二乗 法によってその勾配を求めると、 -0.63 と示された。これ から、不安増波から得られたりターンマップのフラクタ 儿次元（以後、不安脳波のフラクタル次元と略記）は、 0.63 と推定された。

平面図形のフラクタル次元は、理論的には $0 \sim 2$ と言わ れているので、上記の各值はその範囲内である。因みに、 不安脳波のフラクタル次元 0.63 は、カントールの 3 進集 合の次元 0.631 に非常に近く、警戒脳波のフラクタル次 元 0.56 は、小豆島海岸線のフラクタル次元 1.17 の半分く らいである。また、平常脳波のフラクタル次元 0.70 は、 コッホ曲線や、四万十川のフラクタル次元 1.26 の半分よ りは大きい值である。

比較の便のために、平常脳波、不安脳波、及び警戒腷 波の 3 者の $\operatorname{lnd}-\ln \mathrm{N}(\mathrm{d})$ 特性を 3 次元座標上に一括して描 いたものを Fig. 30 に揭げた。 


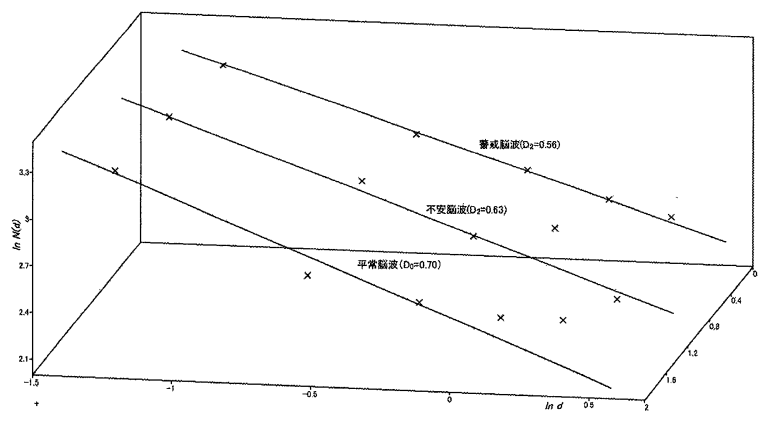

Fig.30. Three kinds of $\ln d-\ln N(d)$ characteristic.

一般に、フラクタル次元の記号は D が用いられている ので、本稿でもそれに従った。そこで、Fig.30 では、平 常脳波のフラクタル次元が $\mathrm{D}_{0}$ 、不安脳波のフラクタル次 元が $\mathrm{D}_{1}$ 、警戒脳波のフラクタル次元が $\mathrm{D}_{2}$ として記入 されている。同図から三つの状態を見ると、平常状態か ら、不安状態に移行し、警戒状態になるにしたがって、 フラクタル次元は減少している傾向が窥える。これは、 不安な感情から警戒心がおこると、脳の働きは複雑さか ら単純な方向一向かい、その結果、フラクタル次元が減 るのではないかと思われる。

\section{III-E. Attempt to numerical valuation}

リターンマップのフラクタル次元は、図形の複雑さを 表しているが、その数值の評価は人によって異なる。一 般化のためには、ある種の規格化（Normalization）が必 要である。例えば、鉄を重いと感ずる人と、金を重いと 感ずる人とが、同じ場で重さを論ずるには、同じ体積に して、比重の概念で比較せねばならないように、何か基 準になる量で、表された量を割ってやる必要がある。本 稿では、基準になる量として、平常脳波のフラクタル次 元を選んだ。理由は、平常状態がいわゆる定常状態で、 悪臭を嗅いだときは過渡状態と仮定したからである。ま た、実験した三状態のうち、平常状態のフラクタル次元 が最も大きかったので、規格值は 0 より大きく 1 より小 さくなる利点があった。そこで、本稿で対象とした「不 安」と「警戒心」に対する数值化の試みとしとして、次 式を導入した。

$$
F_{n} \approx \eta\left(1-D_{n} / D_{0}\right)
$$

ここで、 $(\mathrm{n}=0,1,2)$

$\eta$ : 補正係数、 $\mathrm{D}$ : フラクタル次元、 $\mathrm{F}$ : 心の動摇 添え字 0 : 平常状態、 1 : 不安状態、2 : 警戒状態

いま、上式に、 $\eta=1$ として、D の各值を入れると、 $\mathrm{F}_{0}=0$ で、平静な心を示し、 $\mathrm{F}_{1}=0.1$ で、不安により心 は $10 \%$ 程度動摇していることを示し、 $F_{2}=0.2$ で、警
戒心により心は $20 \%$ 程度動摇していることを示してい る。これらの值は、脳波の振幅の大きさと一致すること がわかった。

\section{CONCLUSION}

覀臭を嗅いだときの被験者の脳波を測定して得られた 基礎データに対して、カオス解析とフラクタル次元解析 を行った結果、次のような結論を得た。

(1) 脳波のリターンマップを解析することは、入ること の困難な人の心の内部に入るこのできる有用な手段と思 われる。

（2）脳波のリターンマップの複雑さを調べると、平常状 態のフラクタル次元は 0.70 、不安状態のフラクタル次元 は 0.63 、警戒状態のフラクタル次元は 0.56 と言う值が得 られた。

(3) 心の動摇を数值化する試みとして、フラクタル次元 を用いて表す簡単な式が導入された。これを用いると、 平常状態では 0.0、食中毒に対する不安状態は 0.1 、食中 毒に対する警戒状態は 0.2 と言う值が得られた。

\section{ACKNOWLEDGEMENT}

筆者が東海大学を退職後も、本研究を継続できたのは、 東海大学理事・香取草之助先生の温かいご激励のお陰で ある。ここに心から感謝申し上げます。また、本研究を 行うに当たって、貴重なご示唆を下さり、多くのご指導 を賜った東海大学名誉教授東良先生に心から御礼申しあ げます。

\section{REFERENCES}

${ }^{1}$ H.Nakajima: "ELECITER" No.75 SPRING, 28 (2000)

2 T.Tachibana: "We master the brain", Asahi Shimbun Publishing (1996)

${ }^{3}$ C.A.Skarda and W.J.Freemann: Behavioral and Brain Science, Vol. 10,161 (1987)

${ }^{4}$ Francis Crick: "The Astonishing Hypothesis", Nakahara hideomi and Sagawa takashi(translation): "Is there soulin the DNA", KODANSHA Ltd. (1995)

${ }^{5}$ Y.Takahashi: An introduction to differential equation, Tokyo University publication meeting (1989)

${ }^{6}$ K.Aihara:"Foundation and application of the chaos theory" Science company(1991) 
${ }^{7}$ H.Haken:"Advanced Synajeetics" ,Springer(1983) Saitou nobuhiko,Komori takeshi,and Ngashima tomomasa (translation) : "Foundation of Synajeetics", Tokai University publication meeting (1990)
${ }^{8}$ S.Ishimura and Ishimura sonoko: "Fractal mathematics", Tokyo literature Co. Ltd.(1992)

SAS Award (Prize of Innovation) was given to this paper presented as Poster Presentation at the 2002 SAS Intelligent Symposium. 